\title{
A STUDY OF ACADEMIC GENRE: EXPLORING WRITING IN ENGLISH FOR UNIVERSITY PURPOSES WITH VIETNAMESE STUDENTS
}

\author{
Michelle J. Evans* \\ Faculty of Arts, Humanities and Cultures, Language Centre, University of Leeds, \\ 3rd Floor, Parkinson Building, Woodhouse Lane, Leeds, LS2 9JT. UK.
}

Received 6 June 2018

Revised 28 January 2019; Accepted 31 January 2019

\begin{abstract}
Higher Education students in Vietnam are increasingly expected to write in English for university and professional purposes. This study identified the written texts in English that postgraduates had written for university purposes and explored their perceptions of or attitudes towards these. Using a classification of university genres developed from the British Academic Written English (BAWE) Corpus, ten case study students showed how their experiences of genres at lower levels of education had been heavily standardised. At undergraduate levels, English-major students and students studying in Englishmedium instruction were expected to write a wider variety of genres. At postgraduate levels, however, students from all subject areas were also required to write some genres, especially scientific research reports in English. Students' attitudes towards assignments were influenced by effort and achievement levels, and the extent to which they felt prepared to write the type of text required. A number of key writing challenges were identified by students via self-reports and think-aloud protocol methods. Many students felt unprepared to write the genres expected of them, including the need for academic vocabulary and critical thinking. Findings indicated that non-English major postgraduate students (especially those enrolled on science-based courses) could benefit from a genre-sensitive pedagogy at late undergraduate or early postgraduate level.
\end{abstract}

Keywords: academic genre, academic literacy, university writing in Vietnam, BAWE corpus

\section{Introduction}

Due to the spread of the English language combined with the internationalisation of Higher Education, university students in nonAnglophone contexts are increasingly required to graduate with a level of English proficiency (Lillis and Curry, 2006, 2010; Nunan, 2003). English is being used as the global lingua franca (a language used by non-native speakers to communicate with one another) in business, science and trade (Canagarajah, 2007; Crystal, 1999, 2012). Vietnamese students are now obliged to learn English at all

Email: M.J.Evans2@leeds.ac.uk levels of education (Harman et al., 2009). For those students working towards an academic career, the ability to write in English is often a key determinant of their success within the academy within Vietnam and internationally (Bolton, 2008; Curry and Lillis, 2004; Duong and Chua, 2016; Hayden and Khanh, 2010; Hoang, 2013; Huong and Fry, 2004, 2011; Kelly, 2000; Lam, 2011; Pham, 1999; Trần, 2013; Welch, 2011a, 2011b). In 2008, the Vietnamese Ministry of Education and Training (MOET) initiated 'Decision 1400', or 'Project 2020 ' to improve foreign language teaching across Vietnam so all learners can use English (and other foreign languages) competently in their work and communications by 2020 . 
MOET had prioritised the need for better training for English language teachers (Dang et al., 2013, Manh et al., 2017; Pham, 2011) and consequentially much research had focused on teacher practices, perceptions or pedagogy (Ngoc and Iwashita, 2012; Nguyen, 2013; Pham, 2013), rather than a focus on learner views (Tomlinson and Dat, 2004) or what types of texts students are required to write in English as part of their English language learning experiences. In response, this paper aims to contribute new insights in these two areas.

\subsection{The role of sociocultural context in second language acquisition and genre studies}

Student attitudes towards second language (L2) learning and their writing processes are related to the sociocultural context in which the language has been learnt and used (Bayley and Langman, 2011; Canh, in Choi and Spolsky, 2007; Dang, 2010; Harman et al., 2009; Hiep, 2000; Huong, 2008; Hyland, 2002b; Nguyen, 1989; Nguyen, 2015; Pham, 1999; Pham, 2011; Pham, 2012; Phan, 2009; Watson-Gegeo and Nielson, 2003). Using models of first (L1) and second language (L2) writing, students' sociocultural background and their expectations of assignment writing have been found to influence their approach to written assignments (Flower and Hayes, 1981, Hayes and Flower 1983; Manchón and De Larios, 2007; Manchón, 2012; Oxford, 1990; Plakans, 2008). Learner-focused studies within Vietnam have yet to explore how students perceive specific types of writing for university purposes and how these may be linked to aspects of the sociocultural context. As part of the sociocultural turn within second language acquisition (SLA) work, WatsonGegeo (2004) discussed L2 learning, use and production as an 'embodied' experience with a dependency on social, cultural and political influences. Social and cultural models become embedded in learners' L1 and L2 language learning and these underpin 'cultural frames' including 'academic notions about teaching and learning, our assumptions about what constitutes science and how language works' (Watson-Gegeo and Nielsen, in Doughty and Long, 2003: 163). This means that students' university writing experiences, including their preferences and writing challenges, can be influenced by educational decisions related to curriculum, assessment, teaching approaches and subject discipline, in addition to other social or cultural factors. This sociocultural dependency has also been reflected in second language writing (SLW) research (Hyland, 2002b; Karlsson, 2009; Swales, 1990) on written genres within academia.

Indeed, within the field of English for Academic Purposes (EAP), researchers have been particularly interested in the types of texts or genres that students are required to produce and how various aspects of the context influence this writing (Bruce, 2010; Lave and Wenger, 1991; Nesi and Gardner, 2012; Römer and O. Donnell, 2011; Swales, 1990). This type of research has had important implications for curriculum design and pedagogy (Basturkman, 2016; Gardner, 2016; Lap and Truc, 2014; Luu, 2011: Nguyen and Miller, 2012). Hyland (2002a) described genres as 'abstract, socially recognised ways of using language' whereas Swales (1990: 58) described genre as " $a$ class of communicative events, the members of which share some set of communicative purposes". Swales pointed to the 'structured' and 'conventionalised' nature of genre in relation to their 'intent, positioning, form and functional value' (Swales, 1990, cited in Bhatia, 1993: 13). The crucial element of genre is the communicative purpose, this is what provides the internal structure of the genre; although other factors such as the content, form, intended audience and medium could also be considered key influences. Within Vietnam, research about the types of genres that university 
students are expected to write within different subject majors is lacking. Studies have tended to focus on how to improve students' performance in writing specific genres, like argumentative essays or recount texts, rather than a mapping of genres written by different types of students (Lap and Truc, 2014; Luu, 2011a: Nguyen and Miller, 2012).

\subsection{Identifying university genres and research questions}

A UK-based example of this mapping endeavour was undertaken by Nesi and Gardner (2012) when they aimed to establish a 'university-wide classification of student assignment texts'. Using 3000 good-standard student assignments taken from three universities in the UK, the British Academic Written English (BAWE) Corpus was created. They analysed the assignments and course documentation, and interviewed tutors in order to 'obtain a more rounded view' of what students thought about the purposes of their assignments. Assignments from across discipline fields including English and Linguistics were included but texts from students studying English as a Foreign Language (EFL) or English for Academic Purposes (EAP) were not incorporated.

Nesi and Gardner's analysis drew on the work of Swales (1990), the Sydney School and Systemic Functional Linguistics (SFL) (Halliday, 1971, 1990). They deployed Halliday's ideas as to how linguistic choices are made by individuals to create social meaning in a specific context (Halliday, 1971, 1990; Kecskés and Agócs, 2013). The attention here is on the functions of the language and texts that are being created in relation to 'field', 'tenor' and 'mode' or the why, what, who and how of the communication (Halliday and Hassan, 1985). Swales' (1990) concept of 'moves' was also used to analyse where student writers had chosen different rhetorical strategies to achieve their cognitive intentions. For example, writers can 'establish the research field' by either 'asserting centrality of the topic, stating current knowledge or ascribing key characteristics' (Bhatia, 1993: 31). This means that while a genre has a communicative purpose, each move within the genre also has a communicative purpose. Through their analysis, Nesi and Gardner (2012) identified 13 genre families. The term 'family' is used here to show how the texts 'share a central function or are involved in the same disciplinary context' (Nesi and Gardner, 2012: 25). The genre families include: Case study; Critique; Specification Design; Empathy Writing; Essay; Exercise; Explanation; Literature Survey; Methodology Recount; Narrative Recount; Problem Question; Proposal; Research Report (Appendix A). This table also shows lists of genres that were included within each genre family for example, a 'Research Report' often functions to show that students can complete a piece of research including research design, and an appreciation of its significance in the field. These reports often include a research aim or question, followed by investigation, links and relevance to other research in the field. Based on the need for new insights on student views of university writing and genres and drawing on literature within the field of genre studies summarised above, two research questions (below) were used to frame the study:

1. Which genres do (ten) Vietnamese Higher Education students write in English for university purposes?

2. How do (the ten) students perceive writing for university purposes in terms of a) challenge, b) enjoyability and c) usefulness for university and/or other purposes.

\section{Methods, analysis and participants}

A multiple case study design (Yin, 2009) was used to explore the writing experiences and perceptions of ten Vietnamese Masters 
(MA) students from 6 universities across Hanoi and Ho Chi Minh City. The case study students were selected based on the theoretical premise that each case could reveal insight into the writing experiences of individuals while also offering opportunities for case comparisons. The sample was based on a 'maximum variability' design where each case can be understood both intrinsically and instrumentally (Yin, 2009:51). Information from individual participants was compared across cases, identifying key recurring patterns and themes. The themes taken from this comparison are those reported in this paper. English language proficiency was a key consideration in the selection process and all potential participants were invited to participate, regardless of their communicative competence in English. It was important to understand the potential variability or similarities of English language writing experiences of learners with different proficiency levels. All participants were offered a choice of interpreter and all materials were available in Vietnamese. The study did not aim, however, to measure or make a judgment about the participants' English language levels. Two participants were selected from a specialised Science and Technology university, three were chosen from Vietnam National University (VNU), University of Languages and International Studies Hanoi (ULIS), and one student was selected from a university for Economics and Business. In order to balance a high-proficiency-biased sample and to support the maximum variability approach, two of these participants had limited communicative competence in English and studied non-English majors. In Ho Chi Minh City, two participants came from a VNU Humanities and Social Sciences department, one more was enrolled within an international university and one trainee teacher was enrolled within the Vietnamese Open University and was undertaking a Post Graduate Certificate in Education (PGCE) course within an International School which had an embedded teacher training programme.

Each participant took part in up to five weekly face-to-face sessions lasting up to 2 hours. Three students required an interpreter to take part in the research and an extensive validation process was used to ensure their views were accurately represented. Students answered a series of semi-structured interview questions about their English language learning experiences and gave information about their writing experiences. They then identified academic and other genres they had written in English using an adapted version of the classification of genres from the British Academic Written English corpus (Nesi and Gardner, 2012; Gardner and Nesi, 2013) (Appendix A). Students also provided copies of assignments to support their self-reports. Following the analysis undertaken by Nesi and Gardner (2012), the genre of each assignment was identified by assessing the function or purpose of the writing, by reviewing the stages of the piece, and by assessing the use of key words. The analyses included whole text structure and more sentence-level linguistic features. The identification of genres formed part of an individual writing biography for each student that provided an overall picture of the types of writing they had undertaken in English across their life course. In these sessions students were asked to rate the pieces of writing they had undertaken (using a 10-point Likert scale) in terms of a) enjoyability, b) challenge and c) usefulness (for various purposes). The scores were not used as a quantitative measure but were used as a comparison and talking point about why students had preferred some types of writing in English over others (Figure 1). 


\begin{tabular}{|c|c|c|c|c|c|c|c|c|c|c|}
\hline Do not enjoy at a & & & & & & & & & & Enjoy a lot \\
\hline 1 & 2 & 3 & 4 & 5 & 6 & 7 & 8 & 9 & 10 & \\
\hline Not challenging & & & & & & & & & & Very challenging \\
\hline 1 & 2 & 3 & 4 & 5 & 6 & 7 & 8 & 9 & 10 & \\
\hline Not useful (for) & & & & & & & & & & Very useful (for) \\
\hline 1 & 2 & 3 & 4 & 5 & 6 & 7 & 8 & 9 & 10 & \\
\hline
\end{tabular}

Figure 1. Likert scales used to discuss perceptions of writing tasks

Following this, the students undertook a retrospective recall of the writing process they had undertaken to complete a recent assignment, and then took part in a thinkaloud protocol session where they engaged in one or two writing tasks using an adapted version of Plakans' (2008) method. Students received written instructions to complete a writing activity and were asked to share their thinking processes during their writing (Appendix B).

\section{Findings}

The themes outlined below were created via cross-case comparisons made in relation to the genres that students had written and their attitudes towards these genres. Unlike other case study approaches, a more detailed individual account of information from participant has been forfeited in order to share more generalised findings. The first research question aimed to establish which genres students had written in English for university and other purposes. Two recurring trends emerged including a significant standardisation of genre at pre-MA level and the demand for research-related writing in English at MA level regardless of subjectmajor.

\subsection{Standardised genres pre-MA}

The types of genres written at primary, secondary and high school were standardised. These included Exercises, Empathy writing and Reflective recounts (within Narrative Recounts). The Exercise genre family was the most predominant type at all lower levels of education. Exercises are made up of a group of activities that involve a series of responses to questions and they aim to provide 'practice in key skills'. The exercises were almost always taken from the national English language textbook and teachers were reported to have rarely introduced writing tasks from other sources outside of the prescribed textbook. The written exercises were mainly written in the classroom although this did not apply as much when students wrote longer pieces at High School. Two participants said they tended to write longer pieces at home. Referring to high school English classes, one student explained,

\section{'Writing in English takes too long, so} my teacher usually missed that out'.

Grammar gap-fill exercises were the most common type of exercise completed at secondary and high school. They were also used to test grammar and vocabulary within the national English language exams 
each year. Many participants enjoyed these types of exercises because they were familiar with them. Multiple-choice questions were preferred because it was deemed easier to select the correct answer by elimination; scoring high marks and passing exams were key factors related to enjoyability. At lower levels, these types of exercises were the least challenging types of writing although they were reported to become more difficult within English major university entrance exams and specialist high school entrance exams.

The second most predominant genre family at lower levels of schooling was empathy writing, specifically letter-writing. According to Nesi and Gardner (2012: 42), the purpose of these activities is to show an understanding of 'academic ideas by translating them into a non-academic writing'. Most participants had written letters to friends or family, but this was not to show their understanding of academic ideas. Instead, the letter-writing was treated as a type of exercise to practice sentence structuring and appropriate use of vocabulary. This type of practice was deemed to be useful by the students.

\subsection{Writing for research}

Overall, students studying an English language-based subject had more experience of writing critiques, essays and literature surveys although all students were required to write a research report in English. Some non-English majors had been writing research reports in Vietnamese. For example, one student had been writing microbiology laboratory reports in Vietnamese but was due to write a research report in English with the support of his university teacher. The same student was being taught how to write an invitation letter as part of an English course designed for university employees and researchers, but the English programme did not offer support for the type of research report writing required within his MA programme.

Many other students were in the process of writing a research proposal for their graduation thesis. Others were writing a final research report for university and/or for publication. Many participants had first experienced these research-related genres at MA level, although some had limited research-related writing experiences towards the end of undergraduate level. For example, one participant who was studying on the International Standard Programme (which is a four-year undergraduate programme in English medium instruction), had written a research proposal and mini-research reports in English from her third undergraduate year. For those non-English majors who had no experience of writing these types of genres as undergraduate level, this was particularly challenging. A number of other reported writing challenges are summarised below.

\subsection{Writing challenges}

The second research question explored how students perceived writing for university purposes in terms of a) challenge, b) enjoyability and c) usefulness for university and/orother purposes. The descriptions below represent the most prominent views and attitudes voiced by the participants. In summary, participants stated that most MAlevel genres were entirely new to them and they often struggled with idea generation, introduction-writing and the requirement to think and write critically at MA (or any) level. Enjoyability and perceptions of the usefulness of writing various genres tended to be influenced by prior experience of the genre and familiarity with the topic.

Writing challenges related to feeling unprepared to write some types of genres and/ or a lack of familiarity with topics. 
Most participants felt a lack of preparation or scaffolding to complete the types of MA assignments required. For many participants, the genres expected at MA level were new which had an impact on the extent to which they enjoyed a piece of writing or how challenging they found it. A lack of academic vocabulary made writing for university purposes difficult. When participants knew subject-specific vocabulary or where they had access to relevant vocabulary, they found the writing process less challenging but not necessarily more enjoyable. Three non-English Language Teaching (ELT) majors found some assignments most useful for learning subject-related vocabulary. For example, two students found it useful to write a macro-economics assignment in English to learn economics and business-related vocabulary. Difficulties arose when participants had learnt terminology in English and then had to translate assignments into Vietnamese. One student had to translate their undergraduate Business graduation paper into Vietnamese. Finding subject-specific terminology in Vietnamese was challenging because the terms had been learnt in English only.

Many participants distinctly remembered when they were required to think or write 'critically' for the first time. A common response was a sense of unknowing and inferiority to challenge existing literature, research and authors. One student said,

"I started to learn to think critically and to make an assessment of someone else's work during the MA. This was the first time I was taught how to do this. At the beginning, I found it a little difficult because I was never taught it before, even at university when I was an undergraduate student."

Another student spoke about her unwillingness to challenge famous linguistic academics within a 'critical review' assignment. Two further participants reported to have difficulty assessing the reliability of sources and finding 'strong and weak' points in the work of others. English-majors in Hanoi had been taught about the structure of research reports and how to evaluate research reports using a template. Fewer participants discussed how they evaluated the content, ideas or arguments in texts.

\subsection{Useful writing}

For some pieces of work, participants were not sure why they were useful or why they thought they had been asked to write them. Other recurring reasons for writing university assignments were reported as: finding sources, reading, brainstorming, avoiding plagiarism, and engaging in critical thinking. One student explained that a research report was useful for learning how to find relevant sources. Another students' literature review was useful to develop reading skills, especially reading research reports and other academic literature. Two students felt that essay writing and learning about different types of essays (including argumentative essays) were useful for developing idea brainstorming skills and critical thinking skills. A different student spoke about her postgraduate assignments helping to 'train her mind', to think differently and to improve evaluation.

Some undergraduate and MA assignments were regarded as good preparation for graduation papers and research reports. Although many genres were new to participants at MA level, there was a sense of skill refinement throughout a module, semester or course. The third most common response about usefulness of writing related to grammar and subject-specific vocabulary. One students' case study of a Vietnamese company was useful to learn business-related vocabulary. The same message was shared 
by three other non-English majors who had written descriptions (genre) in English and felt this helped them to learn subjectspecific vocabulary better than the general English language classes they had to attend at university. Three students found some essays and 'critical responses' useful to learn phrases they could reuse again in later pieces of writing. Assignments showed a recycling of sentence and paragraph structures that were altered slightly for the different topics. Many participants felt that grammar gap-fill exercises were useful to remember grammar rules, sentence structures and use of pronouns for example.

Assignments that were reported to be useful for employment purposes were job application forms, cover letters and research report writing. Six students had written 'genuine' job and university applications or cover letters in English, but not all of them had practice of writing these beforehand. Those who aspired to work in academia found research report writing useful for future employment, partly due to the desire to be published in English. For business-oriented students, their case study assignments were useful to become familiar with the context in which they could work in the future. Some MA students of English Language Teaching (ELT), who already taught at university level, were undertaking classroom-based research for their teaching roles (as a staff member), as well as research for their MA theses.

\section{Discussion and conclusions}

The findings show how experiences of written genres in English and student perceptions of these are influenced by aspects of the Vietnamese sociocultural context and the wider internationalisation of higher education. This included the standardising impact of national testing and assessment at lower levels of education and the (international) demand for research-related writing at postgraduate level. It would be valuable to undertake a larger mapping of the types of university-level genres that students from a range of disciplines are being asked to produce in English, possibly similar to the BAWE corpus study undertaken by Nesi and Gardner (2012). Educators in Vietnam could then consider to what extent the students are prepared and supported to manage the writing tasks expected of them. If the findings from this study are found on a larger scale, a genresensitive pedagogy could be introduced within English writing classes at early undergraduate or even late high school level.

Based on this analysis, students could then be introduced to a wider variety of genres earlier in their English language classes to better prepare them for the types of writing they will be working towards in higher education and/or employment purposes. Facilitating students earlier on to engage in critical thinking activities and writing could enhance their ability to engage more readily with the types of thinking and evaluative tasks that are required at university-level study. Research indicates that genre approaches to writing are not dependent on proficiency in English language, so students with lower levels of English could engage in genreawareness classes (Hyland, 2002a, 2017). Cho (2014) found that students with lower levels of proficiency can learn and achieve in the same way as those with higher proficiency. In a study of genre pedagogy for genre and lexical-phrase knowledge, Cho (ibid) found that students' final attainment was similar, regardless of their starting levels. Rose and Martin (2012) found that less proficient students gained more than other learners when using a genre approach because their difficulties had been 
partly due to a lack of awareness of schematic structures within discourse communities. In particular, postgraduates from the 'pure' sciences could be better prepared to cope with writing research reports in English from the beginning of their postgraduate studies. Many international universities provide academic writing courses tailored for particular disciplines or subjects i.e. writing for Biology students, and so it may be possible for students from particular disciplines to access this type of subject-specific writing class (i.e. Gardner, 2016). Within this approach, students can learn subject vocabulary in context, which could relieve some of the problems with academic vocabulary reported in this study. These sessions could also support students to undertake text analyses to assess the stages and moves within various types of writing.

Some Vietnamese language educators have already used genre-based approaches in teaching, but it is unclear how prevalent this is in 2019 (Lap and Truc, 2014; Luu, 2011: Nguyen and Miller, 2012). For example, Luu (2011) employed a genre approach to teach the writing of Recount genres to one class of students in a University of Finance and Marketing in Vietnam. In a bid to move away from existing writing strategies where university teachers provided vocabulary lists and gave guiding questions to help students to organise their ideas into paragraphs, Luu wanted to offer students an alternative approach. Lap and Truc (2014) applied a similar genre approach to Luu (2011) and found that the quality of argumentative essays improved significantly. A similar pedagogical approach to teaching university writing was used to teach Vietnamese students how to write Business Request genres (Nguyen and Miller, 2012). Nguyen and Miller's students had already completed a 'Business Correspondence' course but had been using 'inflexible textbook examples and memorisation of formulaic structures' with limited application to the workplace. Although students in this study reported to enjoy writing tasks that they scored well in, they also valued writing that was relevant and meaningful to their professional field. Some students had experience of writing for professional purposes, especially in Business and Science degrees, which was deemed helpful. As Vietnam attracts more international business and as organisations continue to use English as a lingua franca, it could be worthwhile for writing educators to assess how well they are preparing their students to write for professional purposes across subject fields by exploring the range of written genres (in English) graduates are being asked to undertake in companies and organisations in Vietnam. This would require university-industry collaboration where organisations share the types of writing in English that employees typically undertake.

This genre mapping and genre-sensitive pedagogy would largely be dependent on teacher-training and researcher training. There is a reported lack of (teacher) awareness of the importance of genre-based knowledge and skills in academic success (Tuyen et al., 2016). Genre-oriented instruction could become a feature of English language teacher training in Vietnam (Devitt, 2009, 2015; Humphrey et al., 2016; Leon Perez and Martin-Martin, 2016) but there are limited examples of this type of genre-based teacher training in the country. Tuyen et al. (2016) study is one example in which TESOL lecturers were interviewed to identify core components that should be included within a Process Genre Approach to Research Paper Writing; with the intention of designing a curriculum for undergraduates (in Vietnam and Malaysia). At higher education levels, curriculum 
developers in Vietnam have some scope to design their own programs (as cited by Tuyen et al., 2016) and there is still much potential to allow genre-based approaches to inform this endeavour in order to meet the writing needs of students and graduates.

\section{References}

Bhatia V. K. (1993). Analysing Genre - Language Use in Professional Settings. London: Longman.

Basturkman, H. (2016). Developing writing courses for specific academic purposes. In J. Flowerdew, \& T. Costley (Eds), Discipline-Specific Writing: Theory Into Practice (pp. 31). Oxford: Routledge.

Bayley, R. \& Langman, J. (2011). Language socialization in multilingual and second language contexts. In E. Hinkel (Ed.), Handbook of research in second language teaching and learning, ( $2^{\text {nd }}$ ed., pp. 291). New York: Routeledge.

Bolton, K. (2008). English in Asia, Asian Englishes, and the issue of proficiency. English Today, 24(2), 3-12.

Bruce, I., (2010). Academic Writing and Genre: A systematic Analysis. London: Continuum.

Canagarajah, A. S. (2007). Lingua Franca English, Multilingual Communities, and Language Acquisition. Modern Language Journal, 91(5), 923939.

Canh, L. V. (2007). A historical review of English language education in Vietnam. In Y.H. Choi, \& B. Spolsky, (Eds.), English education in Asia: History and policies, (pp. 167-179). Seoul, South Korea: Asia TEFL.

Cho, H. (2014). 'It's very complicated' exploring heritage language identity with heritage language teachers in a teacher preparation program. Language and Education, 28(2), 181-195.

Crystal, D. (1999). The future of Englishes. English Today, 15(2), 10-20.

Crystal, D. (2012). English as a global language. Cambridge: Cambridge University Press.

Curry, M. J. \& Lillis, T. (2004). Multilingual scholars and the imperative to publish in English: Negotiating interests, demands, and rewards. TESOL Quarterly, 38(4), 663-688.

Dang, T. T. (2010). Learner Autonomy in EFL Studies in Vietnam: a discussion from a sociocultural perspective. English Language Teaching, 3(2), 3-9.

Dang, T. K. A., Nguyen, H. T. M. \& Le, T. T. T. (2013). The impacts of globalisation on EFL teacher education through English as a medium of instruction: an example from Vietnam. Current Issues in Language Planning, 14(1), 52-72.
Devitt, A. (2009). Teaching Critical Genre Awareness. In C. Bazerman, A. Boninii, \& D. Figueiredo (Eds.), Genre in a Changing World (pp.337-351). West Lafayette, Indiana: Parlor Press.

Devitt, A. (2015). Genre performances: John Swales' Genre Analysis and rhetorical linguistic genre studies. Journal of English for Academic Purposes, 19, 44-51.

Duong, V. A. \& Chua, C. S. (2016). English as a symbol of internationalization in higher education: a case study of Vietnam. Higher Education Research and Development, 35(4), 669-683.

Ellis, N. C. (1998). Emergentism, Connectionism and Language Learning. Language Learning, 48(4), 631.

Flower, L. \& Hayes, J. R. (1981). A cognitive process theory of writing. College composition and communication, 32(4), 365-387.

Gardner, S. (2016). A genre-instantiation approach to teaching English for Specific Academic Purposes: Student writing in Business, Economics and Engineering. Writing and Pedagogy, 8(1), 117-144.

Gardner, S. \& Nesi, H. (2013). A Classification of Genre Families in University Student Writing. Applied Linguistics, 34(1), 25-52.

Hamid, M. O., Nguyen, H. T. M. \& Baldauf Jr, R. B. (2013). Medium of instruction in Asia: Context, processes and outcomes. Current Issues in Language Planning, 14(1), 1-15.

Harman, G. S., Hayden, M., \& Pham, T.N.B. (2009). Reforming higher education in Vietnam: Challenges and priorities. Dordrecht, Netherlands: Springer.

Hayden, M. \& Khanh, D. V. (2010). Private higher education in Vietnam. In G. Harman, M. Hayden, \& T.N. Pham (Eds.), Reforming higher education in Vietnam: challenges and priorities. Dordrecht, Netherlands: Springer.

Hayes, J. R. \& Flower, L. (1983). Uncovering cognitive processes in writing: An introduction to protocol analysis. In P. Mosenthal, L. Tamar, \& S.A. Walmsey (Eds.), Research on Writing, (pp. 3-30). Hillsdale, NJ: Lawrance Erbaum Associates.

Hiep, P. H. (2000). Traditional versus Modern methods. Teacher's Edition, 2, 20-24.

Hiep, P. H. (2001). Teacher development: A real need for English departments in Vietnam. English Teaching Forum, 39(4), 46-57.

Hoang., V. V. (2013). The role of English in the internationalisation of higher education in Vietnam. Vietnam National University Journal of Foreign Studies, 29(1), 72-80.

Humphrey, S., Mahoob, A., \& Martin, J.R. (2016). Genre Pedagogy in Higher Education: The SLATE Project. New York, NY: Palgrave Macmillan.

Huong, T. T. P. (2008). How Vietnamese Culture influence on Learning and Teaching English. https:// eric.ed.gov/?id=ED522274. 
Huong, L. H. \& Fry, G. (2004). Universities in Vietnam: Legacies, Challenges and Prospects. In P. 1tbach., \& T. Umakoshi. (Eds), Asian universities: Historical perspectives and contemporary challenges, (pp. 199-222). Baltimore, MD: The Johns Hopkins Press

Fry, G. W., \& Huong, P. L. (2011). Vietnam as an Outlier: Past, Tradition and Change in Education. In C. Brock, \& L. Symaco (Eds.), Education in Southeast Asia (pp. 221-243). Oxford: Symposium.

Hyland, K. (2002a). Authority and invisibility: Authorial identity in academic writing. Journal of Pragmatics, 34(8), pp. 1091-1112.

Hyland, K. (2002b). Options of identity in academic writing. ELT Journal, 56(4), pp. 351-358.

Hyland, K. (2017). Metadiscourse: What is it and where is it going? Journal of Pragmatics, 113, pp. 16-29.

Karlsson, A. M. (2009). Positioned by reading and writing: Literacy practices, Roles, and Genres in common occupations. Written Communication, 26(1), pp. 53-76.

Kelly, K. (2000). The Higher Education System in Vietnam. World Education News and Reviews, 3(13), pp. 24-36.

Lam, T. L. (2011). The Impact of Vietnam's Globalization in National Education Policies and Teacher Training Programs for Teachers of English as an International Language: A Case Study of the University of Pedagogy in Ho Chi Minh City. Ed.D. Dissertation, Alliant International University, San Diego: ProQuest LLC.

Lap, T. Q. \& Truc, N. T. (2014). Enhancing Vietnamese Learners' Writing Ability in Argumentative Essays. The Journal of Asia TEFL, 11(2), pp. 62-91.

Lave, J. \& Wenger, E. (1991). Situated cognition: Legitimate peripheral participation. Cambridge: Cambridge University Press.

Leon Perez, I. \& Martin-Martin, P. (2016). On the Importance of a Genre-Based Approach in the Teaching of English for Medical Purposes. Language Learning in Higher Education, 6(1), pp. 31-44.

Lillis, T. M. \& Curry, M. J. (2006). Professional Academic Writing by Multilingual Scholars. Written Communication, 23(1), pp. 3-35.

Lillis, T. M. \& Curry, M. J. (2010). Academic writing in global context. London: Routledge.

Luu, T. T. (2011). Teaching Writing through GenreBased Approach. Theory and Practice in Language Studies, 1(11), pp. 1471-1478.

Manchón, R. M. \& De Larios, J. (2007). On the temporal nature of planning in L1 and L2 composing: A study of foreign language writers. Language Learning, 57(4), pp. 549-593.

Manchón R. M. (Ed). (2012). L2 Writing development: Multiple perspectives. New York: De Gruyter.

Manh, L. D. (2012). English as a medium of instruction at tertiary education system in Vietnam. The Journal of Asia TEFL, 9(2), pp. 97-122.
Manh, L. D., Nguyen, H. T. M. \& Burns, A. (2017). Teacher Language Proficiency and Reform of English Language Education in Vietnam, 2008-2020. In D. Freeman \& L.L. Dréan (Eds.), Developing Classroom English Competence: Learning from the Vietnam Experience (pp.19-33). Cambodia: IDP Education.

Nesi, G. \& Gardner, S. (2012). Genres Across the Disciplines: Student Writing in Higher Education. Cambridge: Cambridge University Press.

Ngoc, K \& Iwashita, N. (2012). A comparison of learners' and teachers' attitudes toward communicative language teaching at two universities in Vietnam. University of Sydney Papers in TESOL, 7, pp. 25-49.

Nguyen, K. (1989). On the historical role of Confucianism. Vietnamese Studies, 94(4), pp. 67-72.

Nguyen, B. T. (2013). Innovating management strategies to improve quality of teaching and learning at colleges and universities in Ho Chi Minh City. Review of Higher Education and Self-Learning, 6(18), pp. 25-55.

Nguyen, T. Q. T. (2015). The Influence of Traditional Beliefs on Vietnamese College Lecturers' Perceptions of Face. Journal of Education for Teaching: International Research and Pedagogy, 41(2), pp. 203-214.

Nguyen, H. \& Miller, J. (2012). Exploring business request genres: Students' rhetorical choices. Business Communication Quarterly, 75(1), pp. 5-28.

Nunan, D. (2003). The impact of English as a global language on educational policies and practices in the Asia-Pacific Region. TESOL Quarterly, 37(4), pp. 589-613.

Oxford, R. (1990). Language learning strategies: What every teacher should know. Boston: Heinle \& Heinle.

Pham, H. H. (1999). The key socio-cultural factors that work against in tertiary English language training programs in Vietnam. In J. Shaw., D. Lubelska., $\&$ and M. Noullet (Eds.), Proceedings of the Fourth International Conference on Language and Development (pp.187-198). Bangkok, Thailand: Asian Institute of Technology.

Pham, T. T. H. (2011). Issues to Consider when Implementing Student-Centred Learning Practices at Asian Higher Education Institutions. Journal of Higher Education Policy and Management, 33(5), pp. 519-528.

Pham, T. T. H. (2012). A Framework to Implement Cross-Cultural Pedagogy: The Case of Implementing Learning Reform at Confucian Heritage Culture Colleges. Higher Education Review, 44(3), pp. 27-40.

Pham, L. A. (2013). A case study into English classroom assessment practices in three primary schools in Hanoi: Implications for developing a contextualized formative assessment practice framework. Vietnam National University Journal of Foreign Studies, 29(1), pp. 1-16. 
Phan, T. H. (2009). Impact on Vietnams' Social Context on Learner' Attitudes Towards Foreign Languages and English Language Learning: Implications for Teaching and Learning. Asian EFL Journal, 11(1), pp. 169-184.

Plakans, L. (2008). Comparing composing processes in writing-only and reading-to-write test tasks. Assessing Writing, 13(2), pp. 111-129.

Römer, U. \& O. Donnell, M.B. (2011). From student hard drive to web corpus (part 1): the design, compilation and genre classification of the Michigan Corpus of Upper-level Student Papers (MICUSP). Corpora, 6(2), pp. 159-177.

Rose, D. \& Martin, J. R. (2012). Learning to Write, Reading to Learn: Genre, knowledge and pedagogy in the Sydney School. Equinox.

Schneider, M. \& Fujishima, N. (2007). When practice doesn't make perfect: the case of a graduate EFL student. In B. Belcher., \& G. Braine, G. (Eds.), Academic Writing in a Second Language: Essays Research and Pedagogy (pp. 3-22). Norwood, NJ: Ablex.

Swales, J. M. (1990). Genre analysis: English in academic and research settings. Cambridge: Cambridge University Press.

Tomlinson, B. \& Dat, B. (2004). The Contributions of Vietnamese Learners of English to ELT Methodology. Language Teaching Research, 8(2), pp. 199-222.

Trần, T. T. (2013). Internationalization of Higher Education in Vietnam Opportunities and Challenges. Vietnam National University Journal of Foreign Studies, 30(3), pp. 61-69.
Tuyen, K. T., Bin Osman, S., Cong, D.T. \& Binti, A. (2016). Developing Research Paper Writing Programs for EFL/ESL Undergraduate Students Using Process Genre Approach. Higher Education Studies, 6(2), pp. 19-29.

Võ, T. H. Y. (2014). Cultural Differences: A Barrier to Native English Teachers in English as a Foreign Language Contexts. Vietnam National University Journal of Foreign Studies, 30(1), pp. 63-72.

Watson-Gegeo, K. A. (2004). Mind, Language, and Epistemology: Toward a Language Socialization Paradigm for SLA. Modern Language Journal, 88(3), pp. 331-350.

Watson-Gegeo, K.A \& Nielson, S.E. (2003). Language socialisation in SLA. In C. Doughty., \& M.H. Long (Eds.), The Handbook of Second Language Acquisition (pp.155-177). Malden: Blackwell.

Welch, A. (2011). Higher Education in South-East Asia: Achievement and Aspiration. In C. Brock \& L. Pe Symaco (Eds.), Education in South-East Asia (pp. 265-282). Oxford: Symposium.

Welch, A. (2011b). Higher Education in Southeast Asia: Blurring Borders, Changing Balance. Routledge Research on Public and Social Policy in Asia. London: Routledge.

Wilkinshaw, I. \& Duong, O.T.H. (2012). Native and Non-native Speaking English Teachers in Vietnam: Weighing the Benefits. TESL - EJ, 16(3), pp/1-17.

Yin, R. K. (2009). Case study research: design and methods. London: SAGE. 


\title{
NGHIÊN CƯU THỂ LOẠI VĂN BẢN KHOA HỌC: KHẢO SÁT VĂN BẢN KHOA HỌC TIẾNG ANH CỦA SINH VIÊN, HỌC VIÊN VÀ NGHIÊN CƯUU SINH VIỆT NAM
}

\author{
Michelle J. Evans \\ Khoa Nghệ thuật, Nhân văn và Văn hóa, Trung tâm Ngôn ngũu, Đại học Leeds
}

Tóm tắt: Sinh viên đại học $(\mathrm{SV})$, học viên sau đại học $(\mathrm{HV})$ và nghiên cứu sinh $(\mathrm{NCS})$ Việt Nam phải đáp ứng yêu cầu ngày càng cao về việc viết văn bản khoa học bằng tiếng Anh phục vụ công tác học tập, nghiên cứu và chuyên môn của mình. Nghiên cứu này xác định các loại văn bản viết bằng tiếng Anh mà $\mathrm{HV} \& \mathrm{NCS}$ phải viết trong quá trình học tập, khảo sát nhận thức hoặc thái độ của họ đối với những loại văn bản đó. Sử dụng bảng phân loại thể loại văn bản khoa học trong Khối liệu tiếng Anh văn bản học thuật của Anh (BAWE), 10 HV \& NCS trong nghiên cứu này cho thấy trải nghiệm về thể loại của họ ở các bậc học trước đã được chuẩn hóa mạnh mẽ như thế nào. Ở bậc đại học, $\mathrm{SV}$ chuyên và không chuyên tiếng Anh, hoặc SV sử dụng tiếng Anh làm phương tiện dạy-học phải viết nhiều thể loại khác nhau. Ở bậc sau đại học, HV \& NCS tất cả các ngành cũng phải viết một số thể loại nhất định, đặc biệt là báo cáo nghiên cứu khoa học bằng tiếng Anh. Thái độ của họ đối với các loại hình văn bản này chịu ảnh hưởng của công sức bỏ ra và kết quả thu được, cũng như mức độ được chuẩn bị để viết loại văn bản yêu cầu. Nhiều thách thức lớn trong việc viết văn bản khoa học được HV \& NCS chỉ ra qua các bản tự thuật cũng như phương pháp tư duy thành lời (think-aloud protocol). Nhiều HV \& NCS cảm thấy chưa được chuẩn bị đầy đủ để viết các văn bản khoa học theo yêu cầu, kể cả đòi hỏi về vốn từ vựng khoa học cũng như tư duy phê phán. Những phát hiện qua nghiên cứu này cho thấy HV \& NCS các ngành không chuyên tiếng Anh (đặc biệt là các ngành khoa học cơ bản) có thể sẽ được chuẩn bị tốt hơn nếu giáo viên áp dụng phương thức tiếp cận thể loại khi giảng dạy ở những năm cuối bậc đại học hoặc ngay từ đầu chương trình sau đại học.

Tù khóa: thể loại văn bản khoa học, hiểu biết khoa học, văn bản khoa học ở đại học Việt Nam, khối liệu BAWE 


\section{APPENDIX A}

Adapted version of Gardner and Nesi's (2013) genre categories

\begin{tabular}{|c|c|c|}
\hline Type of writing & Purpose & Examples of writing \\
\hline Case study & $\begin{array}{l}\text { To show understanding of } \\
\text { professional practice by analysing } \\
\text { a single or just one example. } \\
\text { Includes a description of one } \\
\text { person or one organisation with } \\
\text { recommendations or suggestions } \\
\text { for future action. } \\
\text { Often used in Business, Medicine } \\
\text { or Engineering. }\end{array}$ & $\begin{array}{l}\text { - Business start-up company report } \\
\text { - Organisation analysis } \\
\text { - Patient report }\end{array}$ \\
\hline Critique & $\begin{array}{l}\text { To show understanding a topic by } \\
\text { evaluating it and assessing why it } \\
\text { is important or useful. } \\
\text { This might include a description, } \\
\text { maybe some explanation and } \\
\text { evaluation. }\end{array}$ & $\begin{array}{l}\text { - Academic paper review } \\
\text { - Approach evaluation } \\
\text { - } \text { Business/ organisation evaluation } \\
\text { - Financial report evaluation } \\
\text { - Interpretation of results } \\
\text { - Legislation evaluation } \\
\text { - Policy evaluation } \\
\text { - Product/ building evaluation } \\
\text { - Project evaluation } \\
\text { - Review of a book/ film/ play website } \\
\text { - System evaluation } \\
\text { - Teaching evaluation }\end{array}$ \\
\hline $\begin{array}{c}\text { Specification } \\
\text { Design }\end{array}$ & $\begin{array}{l}\text { To show the ability to design a } \\
\text { product or a procedure that could } \\
\text { be manufactured or used by } \\
\text { others. } \\
\text { This might include writing about } \\
\text { its purposes, how the design was } \\
\text { developed and how it was tested. }\end{array}$ & $\begin{array}{l}\text { - Application design } \\
\text { - Buidling design } \\
\text { - Database design } \\
\text { - Game design } \\
\text { - Label design } \\
\text { - Product design } \\
\text { - System design } \\
\text { - Website design }\end{array}$ \\
\hline Empathy Writing & $\begin{array}{l}\text { To show understanding of } \\
\text { academic ideas by translating } \\
\text { them into a non-academic } \\
\text { writing, for example - a letter or } \\
\text { a newspaper article. }\end{array}$ & $\begin{array}{l}\text { - Expert advice to industry } \\
\text { - Expert advice to members of the } \\
\text { public } \\
\text { - Information leaflet } \\
\text { - Job application } \\
\text { - Letter to a friend } \\
\text { - News report }\end{array}$ \\
\hline
\end{tabular}




\begin{tabular}{|c|c|c|}
\hline Essay & $\begin{array}{l}\text { To show ability to create an } \\
\text { argument and use critical thinking } \\
\text { skills. } \\
\text { This includes an introduction, } \\
\text { main arguments and conclusion. }\end{array}$ & $\begin{array}{l}\text { - Compare and contrast } \\
\text { - Discuss }\end{array}$ \\
\hline Exercise & $\begin{array}{l}\text { To give practice in key skills and } \\
\text { show what has been learnt. }\end{array}$ & $\begin{array}{l}\text { - Calculation } \\
\text { - Data analysis mixed (e.g. calculations } \\
+ \text { short answers). } \\
\text { - Short answers to questions } \\
\text { - Statistics exercise } \\
\text { - Fill the gaps }\end{array}$ \\
\hline Explanation & $\begin{array}{l}\text { To show understanding of a topic } \\
\text { by describing it and writing why } \\
\text { it is important. }\end{array}$ & $\begin{array}{l}\text { - } \text { Business explanation } \\
\text { - Instrument description } \\
\text { - } \text { Methodology explanation } \\
\text { - Organism/ disease account } \\
\text { - Site/ environment report } \\
\text { - Species/ breed description system } \\
\text { - Process explanation } \\
\text { - Account of natural phenomenon }\end{array}$ \\
\hline Literature Survey & $\begin{array}{l}\text { To show knowledge of important } \\
\text { literature in the topic maybe with } \\
\text { some evaluation of the literature. }\end{array}$ & $\begin{array}{l}\text { - Literature review } \\
\text { - Literature overview } \\
\text { - Research methods review } \\
\text { - Analytical bibliography } \\
\text { - Annotated bibliography } \\
\text { - Anthology } \\
\text { - Review article }\end{array}$ \\
\hline $\begin{array}{l}\text { Methodology } \\
\text { Recount }\end{array}$ & $\begin{array}{l}\text { To show knowledge of } \\
\text { procedures, methods and how to } \\
\text { record experimental findings. } \\
\text { Includes a decription of the } \\
\text { procedures used. }\end{array}$ & $\begin{array}{l}\text { - Research methods report } \\
\text { - Experimental report } \\
\text { - Lab report } \\
\text { - Field report } \\
\text { - Computer analysis report } \\
\text { - Data analysis report } \\
\text { - Materials selection report } \\
\text { - Program development report }\end{array}$ \\
\hline $\begin{array}{l}\text { Narrative } \\
\text { Recount }\end{array}$ & $\begin{array}{l}\text { To show awareness of the motives } \\
\text { and or behaviour of people and } \\
\text { organisations. } \\
\text { This can be a fictional of factual } \\
\text { recount of events. }\end{array}$ & $\begin{array}{l}\text { - Reflective recount } \\
\text { - Biography } \\
\text { - } \text { Character outline e.g. person in a story } \\
\text { - Plot synopsis } \\
\text { - Report of disease breakout } \\
\text { - Accident report } \\
\text { - Account of literature search } \\
\text { - Account of website search }\end{array}$ \\
\hline
\end{tabular}




\begin{tabular}{|c|l|l|}
\hline \multirow{3}{*}{$\begin{array}{c}\text { Problem } \\
\text { Question }\end{array}$} & $\begin{array}{l}\text { To give practice in solving } \\
\text { professional problems. } \\
\text { This may involve being given } \\
\text { a scenario and then offering } \\
\text { possible solutions. }\end{array}$ & - Loginess scenario \\
\hline \multirow{5}{*}{ Proposal } & $\begin{array}{l}\text { To show planning of action for } \\
\text { the future. } \\
\text { This might include the purpose, } \\
\text { detailed plan and persuasive } \\
\text { argumentation. }\end{array}$ & - Book proposal \\
\hline \multirow{5}{*}{ Research Report } & - Catering plan \\
\hline & $\begin{array}{l}\text { To show ability to completea piece } \\
\text { of research, including research } \\
\text { design and an appreciation of } \\
\text { significance in the field. } \\
\text { Includes research aim/ question, } \\
\text { investigation, links and relevance } \\
\text { to other research in the field. }\end{array}$ & - Student research project \\
\hline
\end{tabular}

\section{APPENDIX B}

\section{Plakans' (2008) Writing-only Think Aloud Task 1}

"Most cultures have borrowed from other cultures. Choose a country that you are familiar with and write about something borrowed from another culture. Consider if this borrowing has been helpful or harmful. Write an essay on this topic."

\section{Plakans' (2008) Reading-Writing Think Aloud Task 2}

"Globalisation has had a strong impact on the world. One issue of globalisation is cultural borrowing or adaptation. Read the following passages about this issue. Then consider your opinion about the impact of globalization on culture. Write an essay supporting your position and using examples." 